\title{
Multilateralism and the Use of Force: Experimental Evidence on the Views of Foreign Policy Elites
}

When announcing his 2011 decision to intervene militarily in Libya, U.S. President Barack Obama emphasized that "the United States is acting with a broad coalition that is committed to enforcing United Nations Security Council Resolution 1973," which authorized the use of force to protect Libyan civilians. ${ }^{1}$ Similarly, in announcing the start of the 1991 Persian Gulf War, U.S. President George H. W. Bush highlighted that America was acting "in accord with United Nations resolutions" authorizing military action to restore the sovereignty of Kuwait. ${ }^{2}$ Even when the United States fails to achieve (or decides not to seek) the support of the UN Security Council, the U.S. government will often appeal to a regional organization such as NATO for its imprimatur or drape the military operation that emerges as a coalition effort.

This presidential pattern of seeking or trumpeting multilateral backing for military interventions raises the questions of whether and why the approval of international partners influences domestic support for the use of force. An emerging consensus among international relations scholars holds that states often seek the endorsement or participation of multilateral security organizations when using military force because it increases support for their policies among their domestic publics. ${ }^{3}$ A recent wave of research has found empirical support for these claims through the use of survey experiments. ${ }^{4}$

Scholars have advanced a range of theories to explain why multilateral cooperation influences domestic support for war. One set of arguments highlights the importance of

\footnotetext{
${ }^{1}$ Obama 2011.

${ }^{2}$ Bush 1990.

${ }^{3}$ Chapman 2011; Grieco et al. 2011; Thompson 2010; Page and Bouton 2006; Fang 2008; Guardino and Hayes 2017.

${ }^{4}$ Guardino and Hayes 2017; Chu 2017; Chapman 2011; Grieco et al. 2011.
} 
international approval in providing legitimacy for military action. ${ }^{5} \mathrm{~A}$ second perspective holds that the public typically supports the use of force when it is approved by an international organization (IO) because multilateral participation spreads the burden of military action. ${ }^{6}$ A third view highlights the role of IOs in providing new information to public audiences about the wisdom of military action. ${ }^{7}$ As Grieco et al. (2011: 564) argue, IO support matters because "members of the public look to IO support for the use of military force as a way of getting a 'second opinion' on whether going to war, as urged by their national leaders, is a good or bad idea."

However, an important gap in the literature on multilateralism and the use of force is that it has given much less attention to the attitudes of foreign policy elites. ${ }^{8}$ We define foreign policy elites as the community of individuals with professional experience or expertise related to foreign policy and international affairs. Scholars have identified a number of ways in which the views of these elites have disproportionate influence over the conduct of foreign policy, including through participating directly in foreign policy decision-making, agenda-setting, and framing effects. ${ }^{9}$ Moreover, the effect of multilateral backing on the domestic politics surrounding use of force decisions may operate primarily through elites, rather than through the public. Many theories of public opinion argue that the public, particularly low-information voters, relies at least in part on elite cues in forming judgments about foreign policy decisions. ${ }^{10}$ Political leaders may therefore seek IO approval as a strategy for building support for their military force proposals among fellow elites.

\footnotetext{
${ }^{5}$ Hurd 2008; Finnemore 2004; Barnett and Finnemore 2004; Hurrell 2005; Cortell and Davis 1996.

${ }^{6}$ Drezner 2008; Milner and Tingley 2013; Recchia 2015; Recchia 2016.

${ }^{7}$ Chapman 2011; Grieco et al. 2011; Fang 2008; Thompson 2010; Chapman and Reiter 2004; Voeten 2005.

${ }^{8}$ Exceptions include Kreps 2011; Recchia 2015; Recchia 2016. See also Schultz 2003.

${ }^{9}$ Saunders 2015; Hafner-Burton, Hughes, and Victor 2013; Jacobs and Page 2005.

${ }^{10}$ See, for example, Guisinger and Saunders 2017; Berinsky 2009; Chong and Druckman 2007; Zaller 1992. For an alternative view, see Kertzer and Zeitzoff 2017.
} 
Yet the causal mechanisms scholars have identified to explain why multilateral cooperation influences support for the use of military force may operate differently for foreign policy elites than for the public. From the perspective of the legitimacy and burden-sharing explanations, foreign policy elites may be more responsive to multilateral approval than members of the public because they are more knowledgeable of the potential legitimacy or burden-sharing benefits that follow from multilateral cooperation. Conversely, if the effect of multilateral approval operates primarily through an information signaling mechanism, this approval may have a weaker effect on elite opinion than on the public. Elites are generally better informed than the public about foreign policy issues, and may therefore rely less on information cues, such as multilateral endorsements, as shortcuts to assess whether a particular policy is worth pursuing. As a result, elites may not need a "second opinion" to judge the merits of use of force proposals.

Does multilateral approval have a similar impact on support for the use of military force among foreign policy elites and the public? We investigate this question by pairing a unique survey of U.S. foreign policy elites across a range of professional fields - including government, journalism, academia, think tanks, and interest groups - with a separate survey of a nationally representative sample of the U.S. public. Both surveys featured an experimental design that measured respondents' attitudes toward military action under different conditions. The survey experiment asked respondents whether they supported or opposed the use of military force in seven potential conflict scenarios, and randomly assigned respondents to a condition in which the hypothetical use of force in each scenario was unilateral or a condition in which the use of force in each scenario was authorized by the United Nations Security Council (UNSC). ${ }^{11}$

\footnotetext{
11 To the best of our knowledge, this paper presents the first experimental analysis of an international issue conducted with both a broad cross-section of foreign policy elites and the general public. Previous experimental studies of elite opinion have either focused on narrower segments of elites such as former military officers, or have used proxies for "eliteness" such as education. See Yarhi-Milo, Kertzer, and Renshon 2018; Hafner-Burton, LeVeck, and Victor 2017; Findley et al. 2017; Renshon 2015; Milner and
} 
We find strong evidence that U.S. foreign policy elites are more responsive to multilateral approval than the U.S. public. Among foreign policy elites, UNSC endorsement increased support for military force in six of seven conflict scenarios, and by an average of 15 percentage points. Moreover, this effect remained large when restricting the sample to the subset of elites with direct experience in foreign policy decision making (those who were serving in a foreign policy position in the executive branch at the time of the survey, or had formerly served in such a position), and when looking at both Republican and Democratic elites. In contrast, among the U.S. public, UNSC authorization increased support for the use of force in just three of seven scenarios, and by an average of only six percentage points. The gap between elites and the public also spans both parties - both Republican and Democratic elites were more responsive to UNSC authorization than their public co-partisans. In addition, the elite-public gap holds even when controlling for measures of pro-internationalist, pro-UN, and pro-military superiority attitudes. These findings suggest that foreign policy experience or knowledge, rather than broad policy attitudes, may lead decision makers and experts to see multilateralism differently than the public - underscoring the importance of surveying foreign policy elites directly. Collectively, our findings point to the importance of considering differences between elites and the public, and among subsets of elites and the public, when investigating or theorizing about the domestic impact of multilateralism.

This research note is organized as follows. The first section lays out competing perspectives in the literature on attitudes toward multilateralism and military force, as well as alternative explanations for why elites might respond to multilateral cooperation differently than the public. The second section describes our elite and public surveys, and the design of the survey

Tingley 2013; Mintz, Redd, and Vedlitz 2006. Other studies have surveyed general foreign policy attitudes among foreign policy elites, including the gap between elite and public attitudes, but without an experimental design. See, for example, Pew Research Center 2013; Page and Bouton 2006; Holsti 2004; Murray 1996; Wittkopf 1987. 
experiment. The third section presents our results. The final section discusses the implications of our findings and avenues these data open up for further research.

\section{Perspectives on Multilateralism and the Use of Force}

Previous research has focused on two main questions relating to multilateralism and the use of military force. First, does multilateral approval increase support for the use of force? Second, if so, what are the dominant causal mechanisms underpinning this preference for multilateral cooperation?

On the first question, many surveys, such as the Chicago Council on Global Affairs' (CCGA) long-running survey of U.S. public opinion on foreign affairs, have consistently found large majorities in favor of supporting multilateral security organizations such as the UN and NATO and participating in new international security institutions such as the International Criminal Court. ${ }^{12}$ Based on the CCGA data, for example, Page and Bouton (2006: 139) conclude that "most Americans ... reject unilateralism in favor of international cooperation and multilateralism.” More recently, studies using survey experiments have generally found that greater multilateral involvement leads to greater public support for the use of force. ${ }^{13}$

However, several scholars have offered different interpretations of survey data on public attitudes towards multilateralism. One view argues that American support for multilateralism is limited to low-cost operations or issues that do not affect important U.S. national interests, or that the public's commitment to acting through IOs is quickly abandoned or ignored when necessary. Based on the Pew Global Attitudes survey, Kohut and Stokes (2006: 179-180) argue that "If

\footnotetext{
${ }^{12}$ Chicago Council on Global Affairs 2012; Pew Research Center 2013. Key works in the larger literature on U.S. public foreign policy attitudes, including attitudes towards international cooperation and war, include Holsti 2004; Jentleson 1992; Jentleson and Britton 1998; Wittkopf 1990; Berinsky 2009; Page and Bouton 2006; Gartner and Segura 1998.

${ }^{13}$ Guardino and Hayes 2017; Chu 2017; Chapman 2011; Grieco et al. 2011.
} 
asked to choose, Americans prefer proactive, assertive unilateral action to multilateral efforts beset by delay and compromise." ${ }^{14}$ Others suggest that the portrait of public enthusiasm for multilateralism is more nuanced, given the low salience of foreign policy generally and the paucity of consistent survey questions about multilateral instruments. ${ }^{15}$

The research literature is also divided over why citizens might - at least in some cases prefer multilateralism to unilateralism when evaluating proposals to use military force. Many theories found in this debate can be bundled within three families of explanations. The first perspective argues that many people support multilateralism because they believe in the normative legitimacy of IOs. In this view, IOs have power because people perceive their rules, procedures, or decisions to be desirable, proper, or sound. ${ }^{16}$ For example, Finnemore (2004: 54) argues that "Unilateral intervention, even for humanitarian purposes, is normatively suspect in contemporary politics and... states will work hard to construct multilateral coalitions for this purpose." An implication of these arguments is that multilateral authorization for the use of force will boost public approval for military action because the public considers IO decisions to be legitimate or right.

The second perspective suggests that the public typically supports multilateralism because it reduces the costs and risks of military action. ${ }^{17}$ Several scholars argue that U.S. leaders and citizens value multilateralism because they see it as a mechanism of burden sharing. Others argue that U.S. presidents pursue multilateral support as a means to signal to domestic audiences or potential veto players that the cost of military action will be shared. According to Recchia (2016: 79), for example, U.S. policymakers have sought multilateral approval in order to "facilitate sustained military and financial burden sharing when they anticipate a potentially open-

\footnotetext{
14 See also Drezner 2008.

15 Busby and Monten 2012.

${ }^{16}$ Hurd 2008; Hurrell 2005; Barnett and Finnemore 2004, 166-170.

${ }^{17}$ Milner and Tingley 2013; Kreps 2011; Recchia 2016; Recchia 2015; Drezner 2008.
} 
ended deployment, in the expectation that such burden sharing will assuage congressional concerns about resource costs.”

The third perspective highlights the information transmission, or signaling, effect of IO authorization of the use of force. ${ }^{18}$ According to this causal logic, members of the public are at an informational disadvantage when evaluating proposals by their national leaders to use military force abroad. Scholars have argued that UN endorsement can boost support for the use of force by providing an informative "second opinion" for the public on the merits of an intervention. This might include signaling that the use of force is likely to succeed, has international political backing, will not be challenged by other powerful states, conforms to the preferences of foreign publics, or is unlikely to be very costly.

While the studies in this literature have generated valuable insights about public attitudes toward multilateralism, very few have examined the attitudes of foreign policy elites. Do foreign policy elites view multilateralism in the same way as the public? The effect of multilateral cooperation on elite support may differ from its effect on the public, but there is currently no evidence on the direction of this effect. On the one hand, since elites are generally more informed about foreign policy, they might already have strong pre-existing views about the merits of use of force proposals and therefore might be less influenced by informational signals provided by multilateral support. On the other hand, multilateral backing might have a greater effect on elites than the public because elites are more aware of the legitimacy or burden-sharing benefits that flow from IO support.

\section{Survey Experiment Design and Fielding}

\section{A. $\quad$ Survey Experiment Design}

\footnotetext{
${ }^{18}$ Grieco et al. 2011; Chapman 2011; Fang 2008; Thompson 2010; Chapman and Reiter 2004; Voeten 2005.
} 
To investigate the effect of multilateral involvement on foreign policy elite attitudes, we embedded an experiment within the 2016 survey of foreign policy opinion leaders conducted by the Chicago Council on Global Affairs (CCGA) and the Texas National Security Network, fielded from August 25 to October 29, 2016. ${ }^{19}$ To investigate whether elites respond differently to multilateral cues than the general public, we embedded the same experiment in a survey of a nationally representative sample of the U.S. adult population, fielded by YouGov from May 22 to June $10,2017 .{ }^{20}$ Both surveys also included questions on a range of foreign policy issues and a set of demographic and partisanship questions. ${ }^{21}$

\footnotetext{
${ }^{19}$ Smeltz et al. 2017.

${ }^{20}$ YouGov interviewed 1251 respondents who were then matched down to a sample of 1000 to produce the final dataset. The respondents were matched to a sampling frame on gender, age, race, education, party identification, ideology, and political interest. See Appendix A4 for a more detailed description of the public survey methodology. One potential concern with comparing data from the two surveys is that the elite survey was fielded prior to the 2016 presidential election, whereas the public survey was fielded after Donald Trump had been elected and taken office as president. Since Trump has opposed or called into question several multilateral institutions and treaties as president, he might have altered how some elites or members of the public view multilateralism. However, Trump had already clearly opposed or called into question key multilateral institutions and treaties during the presidential campaign. It is therefore likely that any effect of Trump's positions on elite or public attitudes would have been manifest by the time of the elite survey. In addition, Appendix Table B8 demonstrates that when comparing the YouGov sample to a nationally representative public sample surveyed by the CCGA prior to the election in June 2016, there is no evidence that the 2016 election shifted aggregate U.S. public attitudes towards internationalism or multilateral cooperation. In both the June 2016 CCGA survey and the May-June 2017 YouGov survey, highly similar proportions of the U.S. public agreed that the U.S. should take an active part in world affairs and that strengthening the UN was a very effective approach to achieving U.S. goals (Smeltz et al. 2016). Future research might further investigate the impact of partisan or campaign priming on domestic attitudes towards multilateral cooperation.

${ }^{21}$ See Appendix C for the full text of the surveys.
} 
In the experiment, respondents were asked whether they favored or opposed the use of U.S. military force in seven scenarios designed to reflect a range of plausible contexts for military intervention: $:^{22}$

- If North Korea invaded South Korea.

- To stop a government from committing genocide and killing large numbers of its own people.

- If Israel were attacked by its neighbors.

- To stop Iran from obtaining nuclear weapons.

- To fight violent Islamic extremist groups in Iraq and Syria.

- To ensure the oil supply.

- To deal with humanitarian crises.

Respondents were randomly assigned to one of two groups. In the first group, the "unilateral" condition, respondents were given the prompt "There has been some discussion about the circumstances that might justify using U.S. troops in other parts of the world unilaterally." In the second group, the UN condition, they were given the prompt "There has been some discussion about the circumstances that might justify using U.S. troops in other parts of the world as part of a United Nations Security Council authorized military mission.”

To confirm that respondents understood that the proposed use of force in all seven scenarios was either unilateral or multilateral, depending on their assigned condition, we included the following question immediately after the use of force question: "In the scenarios you just read about, what do you remember about what the scenarios all had in common:"

- All involved nuclear weapons.

\footnotetext{
${ }^{22}$ To avoid the possibility that responses could be an artifact of the order in which the scenarios were presented, the order of the scenarios was randomized.
} 
- All involved the United States deploying troops as part of a United Nations Security Council authorized mission.

- All involved the United States deploying troops unilaterally.

- All involved North Korea.

This manipulation check question confirmed that a high percentage of elite respondents (approximately 90\%) correctly understood that the proposed use of force in all seven scenarios was either unilateral or multilateral. For the public sample, the comparable figures were $75 \%$ for the unilateral condition, and $68 \%$ for the UNSC condition. To ensure that the comparison of elite and public responses is not biased by the higher failure rate among the public sample, we exclude respondents who failed to correctly identify whether the use of force proposals were unilateral or UNSC-authorized from the analysis. ${ }^{23}$

\section{B. $\quad$ Elite Survey Sample and Fielding}

We generated the distribution list for the elite survey using a variety of sources. ${ }^{24} \mathrm{~A}$ large portion of the list came from Leadership Library (LL), a subscription-based database that includes contact information for individuals in many professional sectors. We also drew on the Teaching, Research \& International Policy (TRIP) database of international relations professors, a U.S. Department of Labor list of major labor unions, the Charity Navigator database of leading NGOs, the University of Pennsylvania's list of top think tanks, and a preexisting CCGA list of religious leaders.

\footnotetext{
${ }^{23}$ Appendix Table B3 confirms that excluding respondents who failed the manipulation check does not alter the covariate balance across treatment and control groups for either the public or elite samples. Appendix Table B7 confirms that the results persist even when including these respondents.

${ }^{24}$ See Appendix A for a full description of how the CCGA Leadership Survey list was compiled and how the survey was fielded.
} 
Using these sources, we identified individuals who had leadership positions and internationally-oriented responsibilities in their field. These included senior and mid-level executive branch officials and congressional aides with responsibility for foreign or defense policy; presidents and vice presidents of interest groups related to international affairs; journalists that cover foreign or defense policy; senior leaders and fellows at think tanks that cover international affairs; and professors of international relations at the top 25 leading U.S. international relations programs. This process produced a total of 484 respondents in six professional sectors. Appendix Table A1 shows, for each professional category, the number of people surveyed, the number of people who responded, and the response rate. Appendix Table B1 shows that elite and public respondents do not substantially differ in their foreign policy outlooks. Large majorities of both samples agreed that the U.S. should take an active part in world affairs. Similar proportions in both samples also agreed that maintaining U.S. military superiority is a very effective approach in achieving U.S. foreign policy goals. However, a larger percentage of public respondents agreed that strengthening the $\mathrm{UN}$ is a very effective approach to achieving U.S. foreign policy goals. Appendix Table B2 confirms that the random assignment of conditions succeeded in generating two samples highly balanced on a set of ideological and demographic covariates.

\section{Results}

We assessed whether there were significant differences in average support for the use of military force between the baseline unilateral condition and the multilateral treatment condition for the full sample of foreign policy elites and the full sample of the U.S. public; the subset of the 
elite sample with direct foreign policy making experience; and Democratic, Republican, and Independent subsets of the two samples. ${ }^{25}$

A. Effect of UNSC Authorization on Support for the Use of Force: Full Elite and Public Samples

For the full sample of foreign policy elites, multilateral approval has a large and consistently positive effect on support for the use of force across a range of conflict scenarios (Table 1). On average, support for the use of force was 15 percentage points higher in the multilateral condition than in the unilateral condition. In only one of the seven scenarios - to ensure the oil supply - was there no statistically significant increase in support in the multilateral condition. In the North Korea and genocide scenarios, UNSC approval increased already large majorities in favor of using military force. In two scenarios - to stop Iran from obtaining nuclear weapons and to fight violent Islamic extremist groups in Iraq and Syria - UNSC approval shifted elite opinion from minority to majority support.

When comparing the elite and public samples, Table 1 demonstrates that UNSC authorization had a weaker effect on support for the use of force among the public than among foreign policy elites. The public's average level of support across all scenarios in the unilateral condition is approximately six percentage points higher than for elites, but three percentage points lower in the UNSC condition. UNSC authorization increased public support for the use of force by an average of six percentage points, and this increase was statistically significant in three of seven conflict scenarios. In four of the seven scenarios, and when averaging all scenarios, the increase associated with UNSC authorization was significantly greater in the elite sample than in the public sample (See Appendix Table B6). Moreover, the differential effect of UNSC

\footnotetext{
${ }^{25}$ All tests of statistical significance in the paper and appendices are chi-square tests, unless otherwise reported. The elite and public results are robust to a number of different weighting approaches, including weighting each professional group in the elite sample equally, and weighting the public sample in each treatment condition to be nationally representative. See Appendix Tables B4 and B5.
} 
authorization among elites and the public remained significant when controlling for party identification and measures of pro-internationalist, pro-UN, and pro-military superiority attitudes (Appendix Table B6). Among the public, UN approval appears to have a weaker effect on public opinion in conflict scenarios involving U.S. allies or balance-of-power issues, such as if South Korea were attacked or to stop Iran from obtaining a nuclear weapon, and a greater effect in scenarios that do not directly engage U.S. national interests, such as to stop a government from committing genocide and to deal with a humanitarian crisis.

Table 1. Effect of UNSC Authorization on Support for the Use of Force

\begin{tabular}{|c|c|c|c|c|c|c|}
\hline \multirow[b]{2}{*}{ Use of Force Scenario } & \multicolumn{2}{|c|}{$\begin{array}{c}\text { Elites } \\
(\mathrm{n}=\approx 383)\end{array}$} & \multicolumn{2}{|c|}{$\begin{array}{c}\text { Public } \\
(\mathrm{n}=716)\end{array}$} & \multicolumn{2}{|c|}{$\begin{array}{c}\text { Executive Branch } \\
(\mathrm{n}=\approx 138)\end{array}$} \\
\hline & Unilateral & UNSC & Unilateral & UNSC & Unilateral & UNSC \\
\hline North Korea & 0.78 & $0.88^{*}$ & 0.68 & 0.69 & 0.80 & $0.95^{*}$ \\
\hline Genocide & 0.72 & $0.88^{*}$ & 0.69 & $0.80 *$ & 0.63 & $0.83 *$ \\
\hline Israel & 0.55 & $0.67 *$ & 0.59 & $0.66^{*}$ & 0.61 & $0.78 *$ \\
\hline Iran Nuclear & 0.36 & $0.55^{*}$ & 0.64 & 0.66 & 0.34 & $0.70 *$ \\
\hline Iraq/Syria & 0.47 & $0.68^{*}$ & 0.58 & 0.65 & 0.43 & $0.75^{*}$ \\
\hline Oil Supply & 0.28 & 0.32 & 0.36 & 0.40 & 0.26 & 0.39 \\
\hline Humanitarian & 0.63 & $0.83^{*}$ & 0.65 & $0.74 *$ & 0.49 & $0.80^{*}$ \\
\hline All Scenarios (Avg.) & 0.54 & $0.69 *$ & 0.60 & $0.66^{*}$ & 0.51 & $0.75^{*}$ \\
\hline
\end{tabular}

Notes: Table reports the proportion of respondents who supported using force in each scenario. Asterisks denote a statistically significant difference with the unilateral condition at the $p<.05$ level.

\section{B. Executive Branch Experience}

This effect holds when restricting the sample to respondents with the direct experience in foreign policy decision making. Table 1 compares the change in support for each scenario by condition for respondents who served in the executive branch in a foreign policy-related position either at the time of the survey or previously in their career. This sample includes current or former foreign policy officials from a range of departments and roles, including Assistant and Deputy Assistant Secretaries in the State and Defense Departments, Directors on the National Security Council staff, Ambassadors, and senior advisors. 
In this group, there is a clear pattern of higher support for the use of force when it has multilateral backing. These officials were on average less supportive of the unilateral use of force than other elites and the public, but on average more supportive than other elites and the public when military force had multilateral approval. Among current or former executive branch officials, UNSC authorization generated a significant increase in support in six of the seven scenarios. The average jump across all seven scenarios was 25 percentage points, with the biggest of these jumps - 36 percentage points - in the Iran scenario.

\section{The Role of Partisanship}

Many scholars argue that party affiliation is a key factor shaping attitudes towards the importance of multilateral organizations and their place in U.S. foreign policy. ${ }^{26}$ In particular, this scholarship shows that Democrats place greater value on multilateral cooperation than Republicans. We would therefore expect to observe significant differences in how Republicans and Democrats, in both the elite and public samples, respond to multilateral approval.

The results from the experiment are largely consistent with this expectation. However, we also find evidence of gaps between elites and the public within both parties (Table 2). On average, both Republican and Democratic foreign policy elites are significantly more likely to support military action when it has multilateral backing. For Democratic elites, support for the use of force was significantly higher in six of the seven scenarios, and on average multilateral backing increased support by 18 percentage points across all scenarios. For Republican elites, the comparable figures were two of seven scenarios and 15 percentage points. ${ }^{27}$ Among elites who

\footnotetext{
${ }^{26}$ Rathbun 2011; Gries 2014; Busby and Monten 2012; Holsti 2004; Wittkopf 1990.

${ }^{27}$ The effect of multilateral support was weakly significant for Republicans elites in the Iraq/Syria scenario $(\mathrm{p}=.098)$. The absence of statistical significance in some of the scenarios among Republicans could be a function of their relatively small sample size (17\% of the elite sample).
} 
identified as Independents, multilateral support did not have a significant effect on support for the use of force in any of the scenarios.

Republican and Democratic members of the public were less responsive to multilateral cues than their party's elites (Table 2). Multilateral backing significantly increased support for the use of force among Democratic members of the public in three of the seven scenarios, and by an average of 11 percentage points. The UNSC's endorsement did not increase support among Republican members of the public in any scenario, and did not generate a statistically significant average increase across the seven scenarios. In conjunction with our results for elites, these results reveal intra-party gaps between elites and the public, as well as gaps between the parties.

Table 2. Effect of UNSC Authorization on Support for the Use of Force by Partisanship

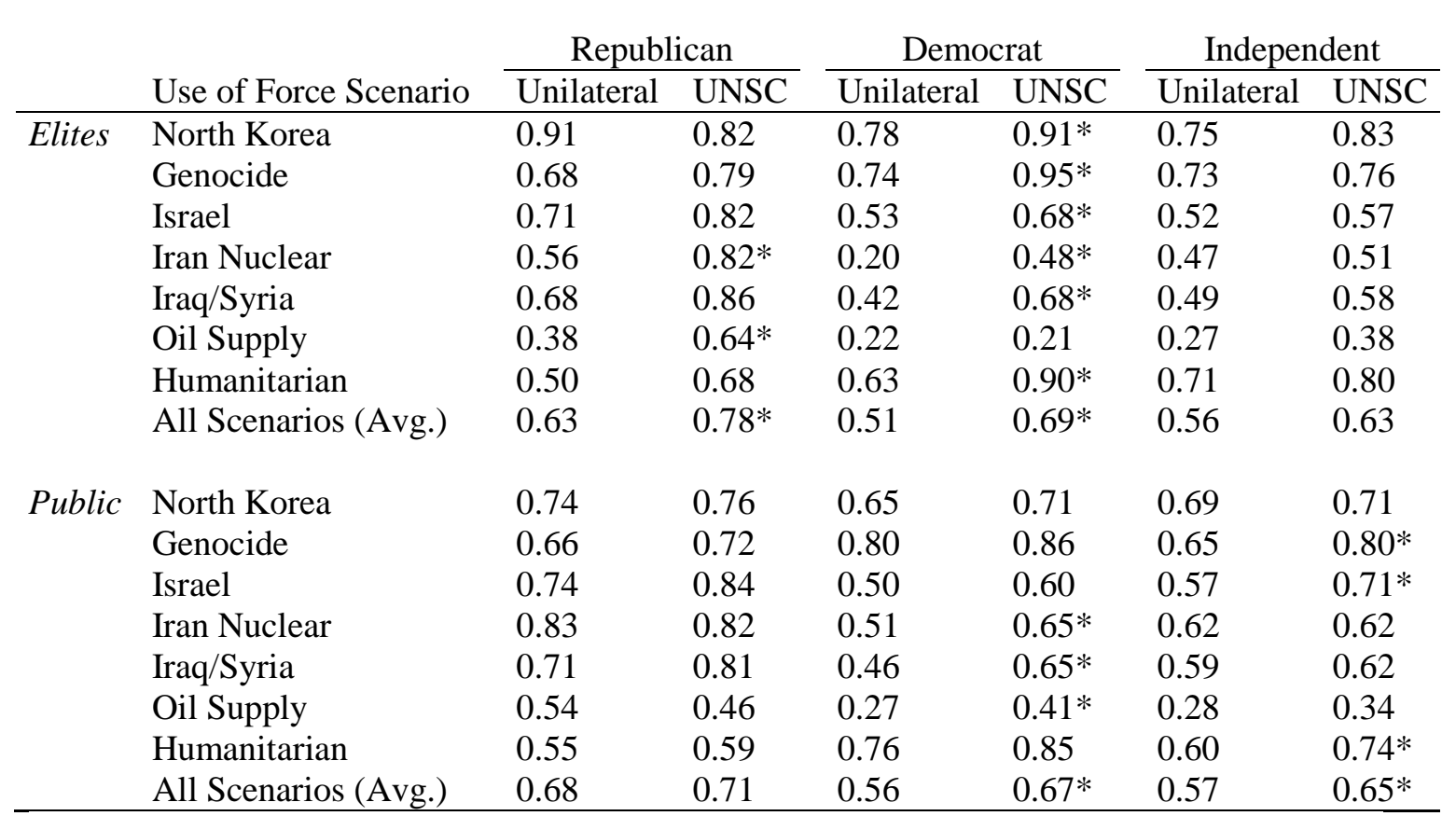

Notes: Table reports the proportion of respondents who supported using force in each scenario. Asterisks denote a statistically significant difference with the unilateral condition at the $p<.05$ level.

\section{Conclusion}

Many international relations scholars have recently coalesced around the claim that multilateral approval increases support for the use of force among domestic publics. Our 
experimental survey findings contribute to the debate over international organizations, domestic politics, and opinion formation in several ways. First, our evidence suggests that multilateral approval matters more to foreign policy elites than to the public, including internationalist members of the public. Second, elites who are directly involved in diplomacy or foreign policy decision making seem to be particularly responsive to multilateralism. Together, these findings suggest that the views of foreign policy elites may be shaped as much by their specialized expertise and experience as by more general attitudinal characteristics. Third, multilateral endorsement has a cross-party effect on the opinions of elites, but does not appear to transcend party lines for the general public. As a result, the opinions of Republican elites are closer to Democratic elites than to Republican members of the public, suggesting that elite-public differences can be at least as important as partisan differences when it comes to international attitudes. Fourth, given that elites have more preexisting knowledge about international affairs than the public, it is likely that their greater responsiveness to multilateral backing is motivated mainly by legitimacy or burden sharing concerns, rather than by the value of a "second opinion."

A key next step is to further investigate the mechanisms driving elite-public, intra-elite, and intra-public differences in foreign policy attitudes, particularly with respect to the three families of explanations we highlighted. Future research might also build on this evidence by investigating whether and how the particular multilateral organization - be it the UNSC, NATO, the African Union, or another institution - endorsing or authorizing a military operation matters. ${ }^{28}$ Additional future work might also examine why certain types of elites or members of the public might be particularly swayed by multilateral cooperation, or whether the patterns identified in these surveys differ among elites and publics outside the United States. Extensions and

\footnotetext{
${ }^{28}$ For instance, Chu 2017 argues that IOs send different cues to domestic audiences depending on the political identities represented by the countries belonging to the IO.
} 
replication studies like these will be important tests of the robustness of these findings and help assess the nature and extent of the impact of multilateral cooperation on domestic audiences. 


\section{REFERENCES}

Barnett, Michael N., and Martha Finnemore. 2004. Rules for the World: International Organizations in Global Politics. Ithaca: Cornell University Press.

Berinsky, Adam J. 2009. In Time of War: Understanding American Public Opinion from World War II to Iraq. Chicago: University of Chicago Press.

Busby, Joshua, and Jonathan Monten. 2012. Republican Elites and Foreign Policy Attitudes. Political Science Quarterly 127 (1): 105-142.

Bush, George H.W. 1990. George Bush: Proclamation 6216-Yosemite National Park Centennial Year, 1990-1991. Available at <http://www.presidency.ucsb.edu/ws/?pid=1922>.

Chapman, Terrence L. 2011. Securing Approval: Domestic Politics and Multilateral Authorization for War. Chicago: University Of Chicago Press.

Chapman, Terrence L., and Dan Reiter. 2004. The United Nations Security Council and the Rally 'Round the Flag Effect. Journal of Conflict Resolution 48 (6): 886-909.

Chu, Jonathan A. 2017. International Organizations and American Public Opinion on Humanitarian War. Working Paper, Stanford University.

Chicago Council on Global Affairs. 2012. Global Views 2012: U.S. Public Topline Report. Available at <http://www.thechicagocouncil.org/publication/global-views-2012-uspublic-opinion-topline-report $>$.

Chong, Dennis, and James N. Druckman. 2007. A Theory of Framing and Opinion Formation in Competitive Elite Environments. Journal of Communication 57 (1): 99-118.

Cortell, Andrew, and James W. Davis. 1996. How Do International Institutions Matter? The Domestic Impact of International Rules and Norms. International Studies Quarterly 40 (4): 451-487.Drezner, Daniel. 2008. The Realist Tradition in American Public Opinion. Perspectives on Politics 6 (1): 51-70.

Fang, Songying. 2008. The Informational Role of International Institutions and Domestic Politics. American Journal of Political Science 52 (2): 304-321.

Findley, Michael G., Adam S. Harris, Helen V. Milner, and Daniel L. Nielson. 2017. Who Controls Foreign Aid? Elite versus Public Perceptions of Donor Influence in AidDependent Uganda. International Organization 71 (4): 633-663.

Finnemore, Martha. 2004. The Purpose of Intervention: Changing Beliefs about the Use of Force. Ithaca: Cornell University Press.Gartner, Scott Sigmund, and Gary M. Segura. 1998. War, Casualties, and Public Opinion. Journal of Conflict Resolution 42 (3): 278-300.

Gries, Peter Hays. 2014. The Politics of American Foreign Policy: How Ideology Divides Liberals and Conservatives over Foreign Affairs. Stanford: Stanford University Press.

Grieco, Joseph M., Christopher Gelpi, Jason Reifler, and Peter D. Feaver. 2011. Let's Get a Second Opinion: International Institutions and American Public Support for War. International Studies Quarterly 55 (2): 563-583.

Guardino, Matt, and Danny Hayes. 2017. Foreign Voices, Party Cues, and U.S. Public Opinion about Military Action. International Journal of Public Opinion Research.

Guisinger, Alexandra, and Elizabeth Saunders. 2017. Mapping the Boundaries of Elite Cues: How Elites Shape Mass Opinion Across International Issues. International Studies Quarterly 61 (2): 425-441.

Hafner-Burton, Emilie M., D. Alex Hughes, and David G. Victor. 2013. The Cognitive Revolution and the Political Psychology of Elite Decision Making. Perspectives on Politics 11 (2): 368-386.

Hafner-Burton, Emilie M., Brad L. LeVeck, and David G. Victor. 2017. No False Promises: How the Prospect of Non-Compliance Affects Elite Preferences for International Cooperation. International Studies Quarterly 61 (1): 136-149. 
Holsti, Ole R. 2004. Public Opinion and American Foreign Policy. Ann Arbor: University of Michigan Press.

Hurd, Ian. 2008. After Anarchy: Legitimacy and Power in the United Nations Security Council. Princeton: Princeton University Press.

Hurrell, Andrew. 2005. Legitimacy and the Use of Force: Can the Circle Be Squared? Review of International Studies 31: 15-32.

Jacobs, Lawrence R., and Benjamin I. Page. 2005. Who Influences U.S. Foreign Policy? American Political Science Review 99 (1): 1-17.

Jentleson, Bruce W. 1992. The Pretty Prudent Public: Post Post-Vietnam American Opinion and the Use of Military Force. International Studies Quarterly 36 (1): 49-73.

Jentleson, Bruce W., and Rebecca L. Britton. 1998. Still Pretty Prudent. Journal of Conflict Resolution 42 (4): 395-417.

Kertzer, Joshua D., and Thomas Zeitzoff. 2017. A Bottom-Up Theory of Public Public Opinion about Foreign Policy. American Journal of Political Science 61 (3): 543-558.

Kohut, Andrew, and Bruce Stokes. 2006. America Against the World: How We are Different and Why We Are Disliked. New York: Times Books.

Kreps, Sarah E. 2011. Coalitions of Convenience: United States Military Interventions after the Cold War. Oxford: Oxford University Press.

Milner, Helen V., and Dustin Tingley. 2013. The Choice for Multilateralism: Foreign Aid and American Foreign Policy. The Review of International Organizations 8 (3): 313-341.

Mintz, Alex, Steven B. Redd, and Arnold Vedlitz. 2006. Can We Generalize from Student Experiments to the Real World in Political Science, Military Affairs, and International Relations? Journal of Conflict Resolution 50 (5): 757-776.

Murray, Shoon Kathleen. 1996. Anchors Against Change: American Opinion Leaders' Beliefs After the Cold War. Ann Arbor: University of Michigan Press.

Obama, Barack. 2011. Remarks by the President on Libya. whitehouse.gov. Available at <https://obamawhitehouse.archives.gov/the-press-office/2011/03/19/remarks-presidentlibya $>$. Accessed 15 September 2017.

Page, Benjamin I., and Marshall M. Bouton. 2006. The Foreign Policy Disconnect: What Americans Want From Our Leaders But Don't Get. Chicago: University of Chicago Press.

Pew Research Center. 2013. Public Sees U.S. Power Declining as Support for Global Engagement Slips. Pew Research Center for the People and the Press. Available at <http://www.people-press.org/2013/12/03/public-sees-u-s-power-declining-as-supportfor-global-engagement-slips/>.

Rathbun, Brian C. 2011. Trust in International Cooperation: International Security Institutions, Domestic Politics and American Multilateralism. Cambridge: Cambridge University Press.

Recchia, Stefano. 2015. Reassuring the Reluctant Warriors: U.S. Civil-Military Relations and Multilateral Intervention. Ithaca: Cornell University Press.Recchia, Stefano. 2016. Why Seek IO approval Under Unipolarity? Averting Issue Linkage vs. Appeasing Congress. International Relations 30 (1): 78-101.

Renshon, Jonathan. 2015. Losing Face and Sinking Costs: Experimental Evidence on the Judgment of Political and Military Leaders. International Organization 69 (3): 659-695.

Saunders, Elizabeth N. 2015. War and the Inner Circle: Democratic Elites and the Politics of Using Force. Security Studies 24 (3): 466-501.

Schultz, Kenneth. 2003. Tying Hands and Washing Hands: The U.S. Congress and Multilateral Humanitarian Intervention, in Locating the Proper Authorities: The Interaction of International and Domestic Institutions, ed. Daniel W. Drezner. Ann Arbor, MI: University of Michigan Press, 105-142.

Smeltz, Dina, Ivo Daalder, Karl Friedhoff, and Craig Kafura. 2016. America in the Age of 
Uncertainty: American Public Opinion and US Foreign Policy. Chicago Council on Global Affairs.

Smeltz, Dina, Karl Friedhoff, Craig Kafura, Joshua Busby, Jonathan Monten, and Jordan Tama. 2017. The Foreign Policy Establishment or Donald Trump: Which Better Reflects American Opinion? Chicago Council on Global Affairs

Thompson, Alexander. 2010. Channels of Power: The UN Security Council and U.S. Statecraft in Iraq. Ithaca: Cornell University Press.

Voeten, Erik. 2005. The Political Origins of the UN Security Council's Ability to Legitimize the Use of Force. International Organization 59 (3): 527-557.

Wittkopf, Eugene R. 1987. Elites and Masses: Another Look at Attitudes toward America's World Role. International Studies Quarterly 31 (2): 131-159.

Wittkopf, Eugene R. 1990. Faces of Internationalism: Public Opinion and American Foreign policy. Durham: Duke University Press.

Yarhi-Milo, Keren, Joshua D. Kertzer, and Jonathan Renshon. 2018. Tying Hands, Sinking Costs, and Leader Attributes. Journal of Conflict Resolution (Forthcoming).

Zaller, John. 1992. The Nature and Origins of Mass Opinion. Cambridge: Cambridge University Press. 